\title{
Host Plant Utilization by Grasshoppers (Orth- optera: acrididae) from a Sandhills Prairie
}

\author{
ANTHONY JOERN
}

\begin{abstract}
Host plant use by 31 species of grasshoppers from a sandhills prairie was determined; gut analysis was used to determine diet. In the composite diet for all species, forbs constituted $37.2 \%$ of the total, grasses and sedges contributed 58\%, and insects made up $4.8 \%$ of the diet. Compared to the plants available at this site, $43 \%$ of the plant species and $36 \%$ of the plant families were included in the composite diet. Although some grasshopper species did not include many host plants in their diet, most included representatives of more than one plant family. Grasshopper species were typically polyphagous with no true specialist feeders. Relatively few plant taxa constituted a large fraction of the composite diet for all grasshopper species and the relative abundance of food plants in the environment appeared to affect the overall use of food plants. Subfamily affinities are obvious. Gomphocerines have the lowest average diet breadth and are primarily grass-feeders while melanoplines feed primarily on forbs and have large average diet breadths; oedipodines are intermediate for these categories. Vegetationdwelling species have significantly lower diet breadths than do ground-dwelling species. Results do not generally support recent theories concerning the evolution of insect herbivore feeding patterns.
\end{abstract}

General patterns of feeding behavior in grasshoppers, such as the number of taxa in the diet, specific food plants, and types of food plants are varied. Determination of feeding patterns and the underlying reasons for observed patterns will undoubtably prove useful for understanding the importance of grasshoppers in range systems. Feeding by entire assemblages of grasshoppers has been examined in creosote-bush deserts (Otte and Joern 1977), arid grasslands (Joern 1979, Ueckert and Hansen 1971), shrub-steppe habitats (Sheldon and Rogers 1978), tall grass pastures (Mulkern et al. 1969), and short-grass prairies and pastures (Mulkern et al. 1969, Pfadt and Levigne 1982). Many other studies have been performed as well to determine the factors influencing host plant selection by grasshoppers (Barton-Browne 1975; Bernays and Chapman 1974, 1978; Gangwere 1961, 1972; Mulkern 1967; Otte and Joern 1977).

The present study provides information on host plant selection by grasshopper species from an arid, sandhills grassland in Nebraska which is composed of both short and tall grasses. Trends seen in the patterns of food plant use will be presented and compared with previous work to examine: (1) degree of specialization of grasshoppers from this site, (2) importance of phylogenetic relationships among grasshoppers and plants associated with host plant selection, (3) types of food plants taken by generalist versus specialist feeders, (4) differences between grass-feeders and forbfeeders, and (5) similarities and differences in feeding behavior by

\footnotetext{
Author is with the School of Life Sciences, University of Nebraska, Lincoln 68588. The author wishes to thank T. Heidorn, M. Kaspari, and N. Rudd for their able assistance in the field. This research was supported in part by NSF Grant RIAS/SER 77-06931 and funds from the University of Nebraska Research Council. Arapaho Prairie is owned by the Nature Conservancy and managed by the School of Life Sciences under a lease agreement through the Cedar Point Biological Station. Author also wishes to thank Dana Wiese for typing the manuscript.

Manuscript received September 30, 1982.
}

the entire assemblage from this site compared with those from different types of grassland and desert systems. These trends will also be discussed in relation to current thoughts concerning the evolution of diet specialization of insect herbivores.

\section{Study Site}

Feeding by grasshoppers was studied at Arapaho Prairie, a grassland research site in the sandhills of Nebraska (Arthur County) in 1978 and 1980. Sandhills prairie is a unique mixed grassland created by dry continental climate in association with extensive sand dunes (Barnes 1980, Keeler et al. 1980). Annual rainfall is approximately $40 \mathrm{~cm}$ of which $80 \%$ falls between April and September. Temperature and rainfall patterns in these 2 years were within the normal range for this site (Jones, unpublished). No striking differences in plant phenologies were observed during the study.

Approximately $\mathbf{2 0 0}$ species of plants from $\mathbf{4 5}$ families have been recorded from this site (Keeler et al. 1980). Perennial tall grasses (both $\mathrm{C}_{3}$ and $\mathrm{C}_{4}$ species) are dominant while grasses typically associated with short-grass prairies are also abundant. Numerous forbs are also present. Dominant species include Bouteloua gracilis, (H.B.K.) Griffiths (blue grama) and B. hirsuta Lag. (hairy grama) which are typically found in short-grass prairies as well as grasses found primarily in tall-grass prairies such as Andropogon hallii Hack. (sand bluestem), Calamovilfa longifolia (Hook.) Scribn. (prairie sandreed), Stipa comata Trin. and Rupr. (needleand-thread grass), and Andropogon scoparius Michx. (little bluestem). Important subdominant species include Agropyron smithii Rydb. (western wheatgrass), Koeleria pyramidata (Lam.) Beauv. June grass), and Carex heliophila Mack. (sedge). Major forbs include: Psoralea tenuiflora Pursh., Ratibida columnifera (Nutt.) Woot. and Standl., Sphaeralcea coccinea (Pursh.) Rydb., Croton texensis (Klotzsch) Muell., Tradescantia occidentalis (Britt.) Smyth., Helianthus rigidis (Cass.) Desf., Ambrosia psilostachya D.C., and Artemisia ludoviciana Nutt. (Keeler et al. 1980). Relative abundances of plants at Arapaho Prairie during the period of this study are reported by Barnes (1980).

Thirty-nine species of grasshoppers have been collected at this site in varying degrees of abundance (Joern 1982). Phenologically, grasshopper species are dispersed throughout the period from late March or April to November with the adult diversity peaking in August and early September. Dominant grasshopper species include Ageneotettix deorum (Scudder), Phoetaliotes nebrascensis (Thomas), Mermiria bivattata (Serv.), Opeia obscura (Thomas), Amphitornus coloradus (Thomas), Melanoplus angustipennis (Dodge), and Melanoplus foedus (Scudder).

\section{Methods}

Diets of grasshoppers were determined through the technique of gut analysis (Mulkern and Anderson 1959, Otte and Joern 1977, Joern 1979). Adult grasshoppers were killed immediately after collection and the foreguts removed and placed in $70 \%$ ethanol 
within an hour after death. Plant fragments from the gut were mounted on slides and compared with permanently mounted fragments taken from plants collected at Arapaho Prairie. Entire slides were scanned. Trichomes, cell wall structures, and stomata patterns were used to identify the plant in the gut. Although most plant fragments could be classified to species, some fragments had no recognizable characters suitable for identification and are lumped as either unknown forbs or grasses. Other fragments had unique characters but could not be matched with plant samples from the study site. These plants were coded as members of the unique but unidentified categories. All insect fragments are lumped since they could not typically be identified as species.

Relative abundances of the plant materials in the diet were estimated. The most abundant material in the gut was scored as such and all other plant species present in the gut recorded as present. These data were then weighted to give the resource utilization of specific food plants by each grasshopper species. In the following analyses, abundant food plants are weighted 3 times as much as the other plants in the gut. This weighting scheme is chosen because the most abundant plant in the gut was immediately apparent and easily dominated the plant species composition of a particular gut sample. Other sampling methods, such as scanning 10 fields per slide, were not employed because individual fragments could not always be identified.

The degree of diet specialization is measured using either the actual number of plant taxa in the composite diet of a grasshopper species or with an index which weights the relative amount of each food plant taken. The index of diet diet breadth (B) used here is:

$$
\text { where } \begin{aligned}
B & =\exp \left(\mathrm{H}^{\prime}\right) \\
\mathrm{H}^{\prime} & =-\sum_{i} \mathrm{p}_{\mathrm{i}} \ln \mathrm{p}_{\mathrm{i}} . \\
\mathrm{H}^{\prime} & =-\mathrm{i}
\end{aligned}
$$

Here, $p_{i}$ represents the proportion of each plant species in the diet of a particular species. The standard error of the $\mathbf{H}^{\prime}$ estimate is calculated according to Poole (1974).

\section{Results}

Species-specific diets for most of the grasshopper species at Arapaho Prairie indicated a wide range in selection of plants. Yet, individual species tended to be relatively restrictive in terms of the particular food plants included in the diet. Overall, 77 food categories (excluding unknown forbs and grasses or flower parts) were found in the guts from these 31 species. This represents $43 \%$ (76/179) of the dry prairie plant species recorded at Arapaho Prairie and 36\%(13/36) of the plant families. In terms of a composite diet for all species (not weighted by abundance or microhabitat use of particular grasshoppers), forbs constituted $37.2 \%$ of the diet,

\begin{tabular}{|c|c|c|c|c|c|c|c|c|}
\hline Grasshopper species & Sample & $\begin{array}{c}\text { Number } \\
\text { of diets } \\
\text { categories } \\
\text { eaten }\end{array}$ & $\begin{array}{c}\text { Diet } \\
\text { B }\end{array}$ & $\begin{array}{l}\text { Number } \\
\text { of plant } \\
\text { families }\end{array}$ & $\begin{array}{l}\text { species } \\
\text { for } \\
\text { of plant } \\
\text { families }\end{array}$ & $\begin{array}{c}\text { Number } \\
\text { species } \\
\text { for } \\
30 \% \\
\text { diet }\end{array}$ & $\begin{array}{c}\text { Number } \\
\text { species } \\
\text { for } \\
50 \% \\
\text { diet }\end{array}$ & $\begin{array}{l}\text { Forbs: } \\
\% \text { of } \\
\text { diet }\end{array}$ \\
\hline \multicolumn{9}{|l|}{ Gomphocerinae } \\
\hline Acrolophitus hirtipes & 50 & 7 & 3.5 & 1.3 & 5 & 1 & 1 & 99 \\
\hline Ageneotettix deorum & 74 & 9 & 5.8 & 1.2 & 3 & 1 & 2 & 1 \\
\hline Amphitornus coloradus & 49 & 6 & 1.8 & 1.4 & 3 & $i$ & 1 & Trace \\
\hline Cordillacris occipitalis & 51 & 9 & 6.2 & 1.3 & 1 & 1 & 2 & 0 \\
\hline Eritettix simplex & 20 & 5 & 4.6 & 1.3 & 2 & 1 & 2 & 0 \\
\hline Mermiria bivittata & 60 & 10 & 7.4 & 1.2 & 3 & $i$ & 3 & 3 \\
\hline Opeia obscura & 50 & 7 & 2.7 & 1.4 & 1 & $i$ & 1 & 0 \\
\hline Parapomala wyomingensis & 50 & 10 & 6.1 & 1.3 & 3 & 1 & 2 & 4 \\
\hline Phlibostroma quadrimaculatum & 50 & 7 & 3.6 & 1.4 & 2 & 1 & 1 & 2 \\
\hline Psoloessa delicatula & 84 & 10 & 5.5 & 1.3 & 6 & $i$ & 2 & 5 \\
\hline \multicolumn{9}{|l|}{ Oedipodinae } \\
\hline Arphia conspersa & 28 & 6 & 3.4 & 1.6 & 3 & 1 & 1 & 8 \\
\hline Arphia pseudonietana & 49 & 14 & 10.2 & 1.3 & 6 & 3 & 4 & 17 \\
\hline Dissosteira carolina & 18 & 15 & 12.7 & 1.4 & 8 & 2 & 4 & 18 \\
\hline Hippiscus ocelote & 16 & 10 & 5.7 & 1.6 & 2 & 1 & 2 & 0 \\
\hline Spharagemon collare & so & 16 & 10.1 & 1.3 & 7 & $i$ & 3 & 11 \\
\hline Trachyrhacys kiowa & so & 6 & 2.0 & 1.4 & 1 & 1 & 1 & 0 \\
\hline Trimerotropis citrina & 15 & 12 & 8.4 & 1.6 & 10 & 2 & 2 & 60 \\
\hline \multicolumn{9}{|l|}{ Melanoplinae } \\
\hline Aeoloplides turnbulli & 51 & 12 & 4.7 & 1.5 & 8 & 1 & 1 & 98 \\
\hline Hesperotettix speciosus & 44 & 14 & 7.3 & 1.4 & 6 & 2 & 2 & 98 \\
\hline Hesperotettix viridis & so & 14 & 4.4 & 1.4 & 5 & $i$ & 1 & 98 \\
\hline Hypochlora alba & 49 & 5 & 1.5 & 1.4 & 6 & i & 1 & 99 \\
\hline Melanoplus angustipennis & so & 23 & 16.5 & 1.2 & 7 & 2 & 5 & 39 \\
\hline Melanoplus bivittatus & 51 & 27 & 19.3 & 1.2 & 13 & 3 & 6 & 75 \\
\hline Melanoplus confusus & 43 & 22 & 15.3 & 1.3 & 15 & 2 & 4 & 90 \\
\hline Melanoplus differentialis & 50 & 20 & 9.2 & 1.4 & 7 & 2 & 3 & 46 \\
\hline Melanoplus femurrubrum & 19 & 13 & 7.3 & 1.6 & 4 & 2 & 3 & 81 \\
\hline Melanoplus flavidus & 50 & 22 & 9.4 & 1.4 & 13 & 1 & 2 & 92 \\
\hline Melanoplus foedus & 46 & 28 & 22.4 & 1.1 & 14 & 4 & 7 & 79 \\
\hline Melanoplus gladstoni & 40 & 22 & 13.9 & 1.4 & 11 & 3 & 4 & 73 \\
\hline Melanoplus sanguinipes & 50 & 29 & 16.8 & 1.3 & 8 & 2 & 5 & 50 \\
\hline Phoetaliotes nebrascensis & 52 & 15 & 11.0 & 1.3 & 8 & 2 & 4 & 11 \\
\hline $\begin{array}{l}\text { Average } \\
\text { (2 S.E.) }\end{array}$ & & $\begin{array}{l}13.7 \\
(2.6)\end{array}$ & $\begin{array}{c}8.4 \\
(1.9)\end{array}$ & & $\begin{array}{c}6.2 \\
(1.4)\end{array}$ & $\begin{array}{c}1.6 \\
(0.3)\end{array}$ & $\begin{array}{c}2.7 \\
(0.6)\end{array}$ & $\begin{array}{c}40.6 \\
(14.6)\end{array}$ \\
\hline
\end{tabular}
grasses, and sedges contributed $58 \%$ of the diet and insects made up

Table 1. Grasshopper diets. Patterns of diet selectivity for each graschopper species are presented to indicate overall patterns of food use. Species are arranged by subfamily. Unknown forbs and grasses are excluded while categories of unique but unidentified plants and insects are included. 
$4.8 \%$ of the diet. Forbs constituted $22 \%$ of the available vegetation at this site (Barnes 1980) while grasses and sedges constituted $78 \%$.

Diet breadths for each grasshopper species are presented in Table I. The average number of categories in the diet is 13.7 and the average value of $B$ is 8.3 . Confidence intervals $(95 \%)$ allow the comparison of diet breadths among species. The fewest number of plants species in a diet was found in Eritettis simplex (Scudder) and Hypochlora alba (Dodge) (5 plant species) and Amphitornus coloradus (Thomas), Arphia pseudonietana (Thomas), and Trachyrhachys kiowa (Thomas) (6 plant species). All except $H$. alba are grass feeders. Grasshopper species feeding on the greatest number of plant species include Melanoplus sanguinipes (Fabr.) (29 plant species), Melanoplus foedus (Scudder) (28 plant species), and Melanoplus bivittatus (Serv.) (27 plant species). Similar results are obtained when diet breadths based on the weighting of particular items (B) are compared. The forb-feeding $\boldsymbol{H}$. alba has the lowest value of B (1.5) followed by E. simplex (1.8) and T. kiowa (2.0). All species with the highest values of B (M. foedus, $M$. bivitattus, $M$. sanguinipes, and $M$. angustipennis) are forb feeders.

No significant relationship exists between $B$ and the percentage of forbs in the diet $(r=0.28, P>0.05)$. Forb feeders are often generalist feeders. A significant positive relationship exists between $B$ and the number of plant families included in the diet $(r=0.77$, $P<0.01$ ).

Relatively few plant species constitute a large fraction of the diets for all grasshopper species. On the average, 1.6 plant species make up 30\% of the diet and 2.7 species make up $50 \%$ of the diet. Even in grasshopper species with the broadest diets, half of the diet is made up of 7 or fewer diet categories. Overall, 7 categories (including insects) make up 50\% of the collective diet for all species. This represents $9 \%(7 / 77)$ of the total categories eaten by this assemblage of grasshoppers.

The relative abundance of food plants in the environment appears to affect the overall utilization of food plants. Relative food plant use within the collective grasshopper diet is positively and significantly correlated with the relative abundance of plants in the habitat $(r=0.8, P<0.01)$, although individual species are selective feeders.

Comparisons of feeding patterns among subfamilies are presented in Table 2. One-way ANOVAs detected significant feeding differences among all subfamilies $(P \leq .05)$. Average values for each subfamily in each category are given along with $95 \%$ confidence intervals for comparisons. The following trends are observed: (1) gomphocerines tended to have the lowest diet breadth (both in terms of number of plant species in the diet and B) while the melanoplines had the greatest diet breadth. (2) The fewest plant families were found in the diets of gomphocerines and the most in melanoplines. (3) Although the diets are typically made up of a relatively small number of plants, a smaller number of plants made
Table 2. Comparisons of diet selectivity among subfamilies of grasshoppers. Means and $95 \%$ confidence intervals are presented for each subfamily. For category of feeding behavior, a one-way analysis of variance was performed to determine if overall differences among subfamilies existed. The asterisk indicates statistical significance. Speciesspecific valus are given in Table 2.

\begin{tabular}{lrrr}
\hline \hline & $\begin{array}{c}\text { Gompho- } \\
\text { cerinae } \\
(\mathrm{n}=10)\end{array}$ & $\begin{array}{r}\text { Oedipodinae } \\
(\mathrm{n}=7)\end{array}$ & $\begin{array}{r}\text { Melano- } \\
\text { plinae } \\
(\mathrm{n}=14)\end{array}$ \\
\hline Feeding Behavior & $4.7(1.2)$ & $7.5(3.7)$ & $11.4(3.6)$ \\
\hline $\begin{array}{l}\text { Diet Breadth** } \\
\text { Number species eaten* }\end{array}$ & $8.0(1.3)$ & $11.3(3.8)$ & $17.1(6.0)$ \\
$\begin{array}{l}\text { Minimum number of plant } \\
\text { families in diet* }\end{array}$ & $2.8(1.2)$ & $5.3(3.1)$ & $8.9(2.1)$ \\
$\begin{array}{l}\text { Number of species for 30\% } \\
\text { of diet* }\end{array}$ & $1.0(0)$ & $1.6(0.6)$ & $2.0(0.5)$ \\
$\begin{array}{l}\text { Number of species for 50\% } \\
\text { of diet* }\end{array}$ & $1.7(0.5)$ & $2.4(1.3)$ & $3.4(1.1)$ \\
\begin{tabular}{l} 
\% forbs in diet* \\
\hline
\end{tabular} & $11.5(22.0)$ & $16.3(19.0)$ & $73.5(15.7)$ \\
\hline
\end{tabular}

$* P \leq 05 \quad * * P<.01$

up $30 \%$ and $50 \%$ of the diets of gomphocerines than was seen in melanoplines which have the greatest number. (4) Melanoplines were typically forb feeders (mean $=73.5 \%$ forbs in diet) while gomphocerines and oedipodines were primarily grass feeders. Exceptions to these generalizations are indicated in Table 1.

Vegetation-dwelling grasshoppers have significantly lower diet breadths than do ground-dwelling grasshopper species (Mann Whitney $U, P<.025$, one-tailed). The diet breadth for species found on vegetation is 5.5 and for ground-dwelling species, B = 10.4. Grasshopper species from disturbed areas tend to have larger diet breadths (mean $B=7.9$ ) although this was not statistically significant (Mann Whitney, $\mathrm{U}, \mathrm{P}=\mathbf{0 . 1 2}$ ). This comparison was conservative in that 3 species with the high diet breadth (Melanoplus confusus (Scudder), M. foedus, and M. sanguinipes), which are very common in disturbed areas, were not included in this group as they are found frequently in other portions of Arapaho Prairie.

\section{Discussion}

Coexisting species of grasshoppers show a wide range of feeding behavior. Although some grasshopper species eat only a few species of plants and others feed on many, grasshoppers are not indiscriminant feeders. This is in keeping with established views (Joern 1979, Mulkern 1967, Otte and Joern 1977).

Cates (1980) proposed the following criteria to delineate the degree of diet specialization: (1) monophagy - 1 or more species within a genus; (2) oligophagy - 2 or more closely related genera, and (3) polyphagy - 2 or more plant families. None of the species

Table 3. Overall patterns of diet selectivity in assemblages of grasshoppers from various habitats. The mean diet breadth (B) and $95 \%$ confidence intervals (C.I.) for the entire assemblage at each site is given.

\begin{tabular}{|c|c|c|c|c|c|}
\hline Study & Habitat & $\begin{array}{c}\text { Number } \\
\text { grasshopper } \\
\text { species } \\
\text { studies }\end{array}$ & $\begin{array}{c}\text { Mean } \\
\text { B }\end{array}$ & $\begin{array}{l}95 \% \\
\text { C.I. }\end{array}$ & Reference \\
\hline Arizona (USA) & Desert & 16 & 2.6 & 0.85 & Otte \& Joern 1977 \\
\hline Argentina & Desert & 12 & 2.8 & 0.66 & Otte \& Joern 1977 \\
\hline Washington (USA) & Shrub-Steppe (Desert) & 8 & 3.7 & 1.42 & Sheldon \& Rogers 1978 \\
\hline Pawnee Site, Colorado (USA) & Shortgrass Prairie & 24 & 4.2 & 1.34 & Pfadt \& Lavigne 1982 \\
\hline Marathon, Texas (USA) & Arid Grassland & 24 & 4.7 & 1.66 & Joern 1979 \\
\hline Kansas (USA) & Tallgrass Pasture & 19 & 5.2 & 1.16 & Mulkern et al. 1969 \\
\hline Altuda, Texas (USA) & Arid Grassland & 22 & 5.7 & 1.66 & Joern 1979 \\
\hline North Platte, Nebraska (USA) & Mixed Prairie/Pasture & 36 & 5.9 & 1.42 & Mulkern et al. 1969 \\
\hline Colorado (USA) & Sandhills Grassland & 14 & 8.2 & 5.08 & Ueckert \& Hansen 1971 \\
\hline Arapaho Prairie, Nebraska (USA) & Sandhills Grassland & 32 & 8.4 & 1.94 & Joern (This Study) \\
\hline North Dakota (USA) & Sandhills Grassland & 32 & 8.6 & 1.53 & Mulkern et al. 1969 \\
\hline
\end{tabular}


considered in this study can be considered monophagous. In all cases, a range of food plants was used, even though some were used infrequently. Some species are oligophagous, but the majority of species must be considered polyphagous using the above criteria.

Compared with other studies (Table 3), diet breadths at Arapaho Prairie are high. A similar methodology for diet determinations was employed in these studies. Grasshoppers from desert sites have the lowest diet breadths (Arizona, $B=2.6$; Argentina, $B=2.7$ ) (Otte and Joern 1977). Diet breadths of grasshoppers from grasslands (western Texas, Kansas, North Dakota, western Nebraska, and Colorado) show higher diet breadths than desert sites. The present study has the second highest average diet breadth $(B=8.4)$. Other sandhills studies also have high average diet breadths (Table 3).

These results also point to the general scavenging role that grasshoppers play by feeding on dead insects. On a composite basis, insect parts contributed $4.8 \%$ of the total diet and ranked fourth in relative importance of all diet categories. Species which included especially high proportions of insect material in the diet were $H$. ocelote $(13 \%), T$. citrina $(20.8 \%), M$. confusus $(16.9 \%), M$. foedus (13.7\%) and $M$. gladstoni $(11.7 \%)$. All of these species except $H$. ocelote are primarily forb feeders and all species would rank as being of relatively large size among species present at this site. However, neither of these factors explains the preponderance of insect material in the diet since many other strictly forb feeders or other large species did not eat insects to any significant degree. Phylogenetic trends in feeding seen here are the same as those seen in previous studies. Gomphocerines are typically grass feeders and have low diet breadth. Oedipodines also feed on grass, or are mixed feeders with an intermediate diet breadth, while melanoplines are primarily forb feeders with high diet breadths.

Many factors are involved in the determination of food selection by grasshoppers. Such factors include: plant chemistry, predictability of the food plant in time and space, phylogenetic constraints, nutrient quality and distribution within the plant, sensory capacities of insects, the types and numbers of all other herbivores feeding on particular plant species, and predation (Bernays and Chapman 1978, Cates 1980, Feeny 1976, Fox 1981, Joern 1979, Otte and Joern 1977, Rhoades 1979, Rhoades and Cates 1976, Rosenthal and Janzen 1979). Secondary plant compounds have been shown to have a great influence over host plant selection through either deterrence or stimulation (Bernays and Chapman 1978).

Feeny (1976) and Rhoades and Cates (1976) have proposed a theory of insect feeding where attributes of the defensive chemistry employed by plants are combined with the likelihood that an insect herbivore will encounter a particular plant. The likelihood that an insect herbivore will encounter a particular plant is referred to as the predictability of the plant. A predictable plant is likely to be found by the insect herbivore. According to this theory, predictable plants are expected to sequester "quantitative" defenses which are typically dosage-dependent and act to deter herbivores by reducing the digestibility of the host plant (such as by complexing proteins and making them unavailable for use). Tannins would be an example of a quantitative defense. Levels of hydrolyzable and condensed tannins in red oak leaves increase after defoliation by gypsy moth larvae (Schultz and Baldwin 1982). Such tannins will affect growth in larval lepidoptera. It is also expected that insects feeding on predictable plants may exhibit high diet breadths compared to those feeding on unpredictable plants.

Unpredictable plants should defend themselves with acutely toxic chemicals which are likely to be "evolutionarily susceptible" to detoxification by herbivores (Feeny 1976, Rhoades and Cates 1976); these toxic chemicals are referred to as qualitative defenses. Alkaloids, mustard oils, and turpenes are examples of qualitative defenses. Herbivores which feed on these plants should be specialist feeders. They are able to detoxify the specific chemicals in a specific plant taxon, but do not have the physiological capacity to detoxify a wide range of chemicals which would be found in a variety of unapparent plants (sensu Feeny 1976, Rhoades and Cates 1976).

Despite the general success of this theory for explaining patterns of food plant use by herbivores, anomalies persist (Bernays and Chapman 1978, Fox 1981, Gilbert 1978, Joern 1979, Otte 1975, Otte and Joern 1977). For example, many grasshopper species are able to adequately deal with tannic acid (considered a quantitative defense) added to food material, contrary to expectations (Bernays 1978, Bernays et al. 1980, Bernays and Chamberlain 1980). Results from the present study do not support these predictions either. Grasshoppers feeding on forbs are encountering a diverse array of defensive chemicals. Yet, they tend to be much more polyphagous than grass-feeding species which are not encountering such chemicals to any great degree.

Food selection revolves around the need for nutrition balanced against the negative effects of antibiotic chemicals (Bernays and Chapman 1978). Grasses and forbs typically represent alternative types of food plants for grasshoppers in this regard. Tradeoffs must exist to explain the evolution of such clear patterns. Costs to grasshoppers feeding on forbs may be expressed as deterred growth, survivorship, or reproduction because of the sequestration of compounds by the plants and subsequent detoxification. Although the presence of particular compounds has been shown to stimulate or inhibit feeding on particular taxa, few studies unequivocably demonstrate negative effects on grasshopper fitness due to the chemical constituents (Bernays and Chapman 1978); some such studies do exist (Harley and Thorsteinson 1967, Navon and Bernays 1978, Schlesinger et al. 1976). However, the great volume of work on other insect groups which does support this view makes it difficult to reject the likelihood of a negative relationship between plant chemicals and fitness in grasshoppers.

Feeding on grasses is one avenue by which grasshoppers may avoid toxic chemicals (Bernays and Chapman 1978). In this process, little or no energy (or other resources) would need to be spent on the detoxification process. For species existing in habitats such as the sandhills grassland at Arapaho Prairie, the food resource is extremely abundant and predictable. However, costs are probably also associated with a grass feeding habit. These might include lowered nutritional quality for such important nutrients as nitrogen and the need to chew the tough, silicaceous leaves of grasses resulting in mandibular wear (McNeil and Southwood 1978, Mattson 1980). Mandibular structures of grass-feeding species of grasshoppers are quite different than those of forb-feeding grasshoppers, and appear suitable for grinding (Isley 1944, Patterson, in press). Wear of mandibular surfaces as a result of feeding on grasses is often noticeable (Chapman 1964).

Some species from subfamilies which are typically grass-feeding also feed on forbs (in some cases exclusively). This suggests that certain reversals in the general feeding habit have taken place (if phylogenies have been correctly inferred) and these are extremely important events in the explanation of the evolution of feeding patterns of grasshoppers. Unfortunately, the data presently available are not sufficient to evaluate these reversals or to explain the phylogenetic relationships associated with the grass-feeding habit. Some insight is provided by Bernays and Chapman (1978).

Predictability of the host plants may greatly influence the diet breadth of grasshoppers. In this regard, grasshoppers feeding on very predictable grasses have low diet breadths. In contrast, forbfeeding grasshoppers using food plants which are unpredictable in time and space have large diet breadths. Species which feed on predictable forbs (such as $\boldsymbol{H}$. alba feeding on Artemisia ludoviciana) have narrow diet breadths as predicted from such reasoning. These results have been demonstrated previously in grasshoppers from other sites as well (Joern 1979, Mulkern et al. 1969, Ueckert and Hansen 1971) and for other herbivorous species (Lawton and Strong 1981). Although the predictability of host plants may explain the number of plants in the diet, it does not explain why some grasshoppers feed primarily on grasses while others feed primarily on forbs. 
Problems remain in explaining the evolution of feeding habits of grasshoppers. Although patterns of feeding in the grass-feeding forms are at least understandable, it is not obvious how forbfeeding species can have such broad diets. Different defensive chemicals in the plants must be dealt with in non-identical ways. This would require a large arsenal of detoxification mechanisms which is not consistent with present expectations (Feeny 1976, Rhoades 1979). Either these views are not correct or other mechanisms must be explored as well. Unfortunately, relevant studies in this area have not been performed.

\section{Literature Cited}

Barnes, P. 1980. Water relations and distributions of several dominant grasses in the Nebraska sandhills prairie. M.S. Thesis. The University of Nebraska at Lincoln.

Barton-Browne, L. 1975. Regulatory mechanisms in insect feeding. Adv. Insect Physiol. 11:1-116.

Bernays, E.A. 1978. Tannins: An alternative viewpoint. Ent. Exp. and Appl. 24:44-53.

Bernays, E.A., and R.F. Chapman. 1974. The regulation of food intake by acridids. p. 48-59. In: L. Barton-Browne (ed). Experimental Analysis of Insect Behavior. Springer Verlag. New York.

Bernays, E.A., and R.F. Chapman. 1978. Plant chemistry and acridoid feeding behaviour. p. 99-141. In: H.B. Harborne (ed.). Biochemical Aspects of Plant and Animal Coevolution: Annual Proceedings of the Phytochemical Society of Europe. No. 15. Academic Press, New York.

Bernays, E.A. and D.J. Chamberlain. 1980. A study of tolerance of ingested tannin in Schistocerca gregaria. J. Insect Physiol. 26:415-420.

Bernays, E.A., D.J. Chamberlain, and P. McCarthy. 1980. A differential effect of ingested tannic acid on different species of Acridoidea. Ent. Exp. and Appl. 28:158-166.

Cates, R.G. 1980. Feeding patterns of monophagous, oligophagous and polyphagous herbivores: The effect of resource abundance and plant chemistry. Oecologia 46:22-31.

Chapman, R.F. 1964. The structure and wear of the mandibles in some African grasshoppers. Proc. Zool. Soc. Lond., 142:107-121.

Feeny. P. 1976. Plant apparency and chemical defense. Rec. Adv. Phytochem. 10:1-40.

Fox, L. 1981. Defense and dynamics in plant-herbivore systems. Amer. Zool. 21:853-864.

Ganzwere, S.K. 1961. A monograph of food selection in Orthoptera. Trans. Amer. Ent. Soc. 87:67-230.

Gangwere, S.K. 1972. Host finding and feeding behavior in Orthopteroids, especially as modified by food availability: a review. Rev. Univers. Madrid 21:107-158.

Gilbert, L.E. 1978. Development of theory in the analysis of insect-plant interactions. p. In: D.J. Horn, R. Mitchell and G.R. Stairs (eds.). Analysis of Ecological Systems. Ohio State Press, Columbus.

Harley, K.L.S., and A.J. Thorsteinson. 1967. The influence of plant chemicals on the feeding behavior, development, and survival of the twostriped grasshopper, Melanoplus bivittatus (Say), Acrididae: Orthoptera. Can. J. Zool. 45:305.

Isley, F.B. 1944. Correlations between mandibular morphology and food specificity in grasshoppers. Ann. Ent. Soc. Amer. 37:47-67. oern, A. 1979. Feeding patterns in grasshoppers (Orthoptera: Acrididae) factors influencing diet specialization. Oecologia 38:325-347.

Joern, A. 1982. Distribution, densities and relative abundances of grasshoppers (Orthoptera, Acrididae) in a sandhills prairie. Prairie Naturalist 14:37-45.

Keeler, K.H., A.T. Harrison, and L.S. Vesclo. 1980. The flora and sandhills prairie, communities of Araphao Prairie, Arthur County, Nebraska. Prairie Naturalist 12:65-78.

Lawton, J.H., and D.R. Strong, Jr. 1981. Community patterns and competition in folivorous insects. Amer. Natur. 108:207-228.

Mattson, W.J., Jr. 1980 . Herbivory in relation to plant nitrogen content. Ann. Rev. Ecol. Sys. 11:119-161.

McNeill, S., and T.R.E. Southwood. 1978. The role of nitrogen in the development of insect/plant relationships. p. 77-98. In: J.B. Harborne (ed.). Biochemical Aspects of Plant and Animal Coevolution. Academic Press. London.

Mulkern, G.B. 1967. Food selection by grasshoppers. Annu. Rev. Entomology 12:59-78.

Mulkern, G.B., and J.F. Anderson. 1959. A technique for studying to the food habits and preferences of grasshoppers. J. Econ. Ent. 52:342.

Mulkern, G.B., K.P. Pruess, H. Knutson, A.F. hagen, J.B. Campbell, and J.D. Lambley. 1969. Food habits and preferences of grassland grasshoppers of the North Central Great Plains. Bull. North Dakota Agr.Exp. Sta. No. 481.

Navon, A., and E.A. Bernays. 1978. Inhibition of feeding in acridids by non-protein amino acids. Comp. Biochem. Physiol. 59:161-164.

Otte, D. 1975. Plant preference and plant succession: A consideration of evolution of plant preference in Schistocerca. Oecologia 18:129-144.

Otte, D., and A. Joern. 1977. On feeding patterns in desert grasshoppers and the evolution of specialized diets. Proc. Acad. Nat. Sci. Phila. 128:89-126.

Patterson, B.D. (In Press). Correlation between mandibular morphology and specific diet of some desert grassland Acrididae (Orthoptera). Amer. Mid. Natur.

Pfadt, R.E., and R.J. Lavizne. 1982. Food habits of grasshoppers inhabiting the Pawnee Site. University of Wyoming Agr. Exp. Sta. of Sci. Monogr.No. 42.

Poole, R.W. 1974. An Introduction to Quantitative Ecology. McGraw Hill. New York.

Rhondes, D.F. 1979. Evolution of plant chemical defense against herbivores. p. 3-54. In: G.A. Rosenthal and D.H. Janzen (eds.). Herbivores: Their interaction with secondary plant metabolites. Academic press. New York.

Rhoades, D.F., and R.G. Cates. 1976. Toward a general theory of plant antiherbivore chemistry. Rec. Adv. Phytochem. 10:168-213.

Rosenthal, G.A., and D.H. Jenzen, (eds.). 1979. Herbivores: their interaction with secondary plant metabolites. Academic Press, New York.

Schlesinger, H.M., S.W. Applebaum, and Y. Birk. 1976. Effect of $\beta$-cyanoI-alanine on the water balance of Locusta migratoria. J. Insect Physiology. 22:1421-1424.

Schultz, J.C., and I.T. Baldwin. 1982. Oak leaf quality declines in response to defoliation by gypsy moth larvae. Science 217:148-151.

Sheldon, J.D., and L.E. Rogers. 1978. Grasshopper food habits within a shrub-steppe community. Oecologia 32:85-92.

Ueckert, D.N., and R.M. Hansen. 1971. Dietary overlap of grasshoppers on sandhill rangeland in northeastern Colorado. Oecologia 8:276-295. 